\title{
UK politicians demand Brexit guarantee for EU scientists
}

Influential committee says researchers need assurances that they can stay after UK leaves European Union.

\section{Daniel Cressey}

18 November 2016

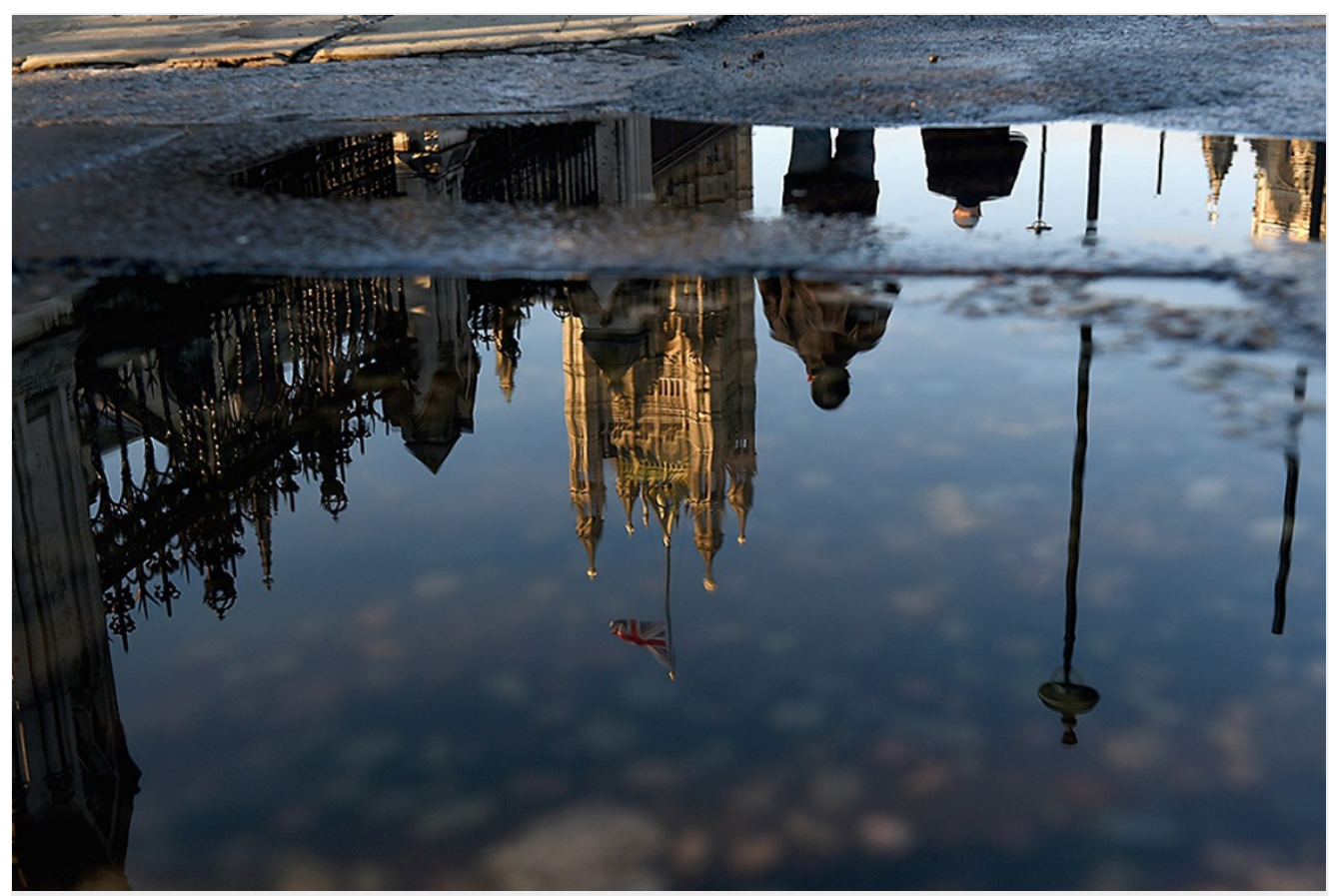

Mary Tumer/Getty

The Brexit vote has thrown the future of EU scientists living in the UK into uncertainty.

The UK government should immediately guarantee that all European Union researchers living in the country can stay after it leaves the EU, an influential group of politicians has said.

The recommendation comes in a report on the impacts of Brexit on science, released on 18 November by the House of Commons science and technology select committee. The report also urges the government to set out a broader vision for science - including committing to a hefty raise in UK science spending.

"Uncertainty over Brexit threatens to undermine some of the UK's ongoing international scientific collaborations. Telling EU scientists and researchers already working in the UK that they are allowed to stay is one way the Government could reduce that uncertainty right away," said Stephen Metcalfe, the chair of the committee and Conservative MP for South Basildon and East Thurrock, in a statement.

Ever since June's Brexit referendum, scientists have fretted about the uncertainty caused for non-British EU nationals, who have been left unsure what their employment rights may be in a few years' time. There are around 31,000 such researchers in the United Kingdom, according to a Royal Society estimate, and they make up about $15 \%$ of UK universities' academic staff.

The committee's inquiry heard from many researchers who were "seriously considering" leaving the country, and the report concludes that reassurances are needed to avoid a brain drain. A group at University College London's Institute of Neurology told the committee that it had polled 67 postdocs, of whom $18 \%$ were actively seeking jobs outside the United Kingdom because of Brexit.

"Some immediate reassurance would be in the interest of the science base and the country," says Graeme Reid, a science-policy researcher at University College London.

\section{Vision for science}

The committee — whose members come from all sides of the political divide — also worries that the government isn't paying enough attention to science as it prepares to leave the EU. "We are not convinced that the needs of science and research are at the heart of 
the Department for Exiting the European Union's (DExEU) thinking and planning for Brexit," the report says.

For example, whereas most UK government departments have a chief science adviser (CSA), DExEU — dubbed the Brexit ministry — doesn't. In a confused episode during the inquiry, science minister Jo Johnson and junior Brexit minister Robin Walker told the committee that they were advertising to fill the role, but later withdrew their statement. Now, says the report, DExEU should recruit someone as a matter of urgency.

The committee adds that the government should commit to raising public and private spending on research to $3 \%$ of UK gross domestic product. It stood at $1.7 \%$ in 2014 , below the EU's $2 \%$ average.

The report notes that the $3 \%$ figure has been suggested many times before, by the committee itself and by science lobby groups. And earlier this week it got another airing, when the four UK national academies — the Academy of Medical Sciences, the British Academy, the Royal Academy of Engineering and the Royal Society — also called on the government to set a 3\% target.

\section{Action points}

Nick Hillman, director of the Higher Education Policy Institute in Oxford, says it is good that the report contains sensible, practical suggestions for science advice and job security, rather than vague requests. "Having a CSA is a clear, practical recommendation that is easily fixed," he says.

Researchers are now waiting anxiously for 23 November, when Philip Hammond, the chancellor of the exchequer, may signal the government's intentions for science in the annual Autumn Statement on government spending. "That's quite an important date for the science and research community," says Hillman.

"I wouldn't place all my bets on an Autumn Statement announcement," says Reid. But he thinks that the government does recognize that science has an important role in the United Kingdom's future.

Another political controversy was partially addressed earlier this week, when the government announced a series of amendments to controversial plans to reform the governance of higher education. The plans aim to bring together several funding bodies — including the seven research councils - into a central funder called United Kingdom Research and Innovation, and to overhaul university governance. But some researchers fear that it might remove universities' autonomy, including their ability to choose what to teach and when.

Johnson says the changes include measures to ensure the autonomy and financial sustainability of universities — including not allowing the government to tell institutions that they must stop or start particular courses.

Nature | doi:10.1038/nature.2016.21015 